\title{
Structure Elucidation of New Monordens Produced by Humicola sp. FO-2942
}

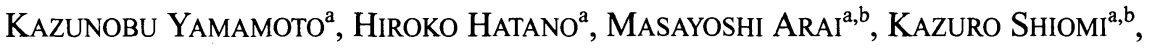 \\ HIROSHI TOMODA ${ }^{\mathrm{a}, \mathrm{b}, \mathrm{c}, *}$ and SATOSHI ŌMURA ${ }^{\mathrm{a}, \mathrm{b}, \mathrm{c}, *}$ \\ ${ }^{\mathrm{a}}$ Kitasato Institute for Life Sciences \& ${ }^{\mathrm{b}}$ Graduate School of Infection Control Sciences, \\ Kitasato University, and ${ }^{\mathrm{c}}$ The Kitasato Institute \\ Minato-ku, Tokyo 108-8641, Japan
}

(Received for publication March 6, 2003)

\begin{abstract}
Structures of three novel compounds designated monordens $\mathrm{C}$ to $\mathrm{E}$, isolated from the fermentation broth of amidepsine-producing fungus Humicola sp. FO-2942, were elucidated by spectroscopic evidence. Monordens C is 6,7-dihydromonorden A. Monordens D and E lack the epoxide moiety of monordens $\mathrm{C}$ and $\mathrm{B}$, respectively.
\end{abstract}

Humicola sp. FO-2942 was originally discovered as a producing fungus of amidepsines, inhibitors of diacylglycerol acyltransferase (DGAT) ${ }^{1)}$. Ten compounds including amidepsines $\mathrm{A}$ to $\mathrm{D}$ were isolated from the culture broth as showing UV spectra similar to amidepsines by LC-UV analyses ${ }^{2}$. Among them, three were identified as monorden ${ }^{3 \sim 6)}$ (radicicol, monorden $\mathrm{A}$ in this paper), its tetrahydro-derivative ${ }^{4,7)}$ (monorden $\mathrm{B}$ in this paper) and 5-O-methylsclerone ${ }^{8)}$, but the others are structurally related new compounds designated monordens $\mathrm{C}, \mathrm{D}$ and E. Tetrahydromonorden (monorden B) and 5-Omethylsclerone were originally reported as synthetic compounds, but we showed that they are fungal metabolites ${ }^{2)}$. The structures of monorden A (1) to E (5) and 5-O-methylsclerone (6) are shown in Fig. 1 . In this paper, we describe the structure elucidation of monordens $\mathrm{C}$ to $\mathrm{E}$ mainly done by NMR analysis. The detailed spectral data of monorden $\mathrm{B}$ and 5-O-methylsclerone is also reported here.

\section{Results}

\section{Structure Determination}

${ }^{1} \mathrm{H}$ - and ${ }^{13} \mathrm{C}-\mathrm{NMR}$ spectra of monorden $\mathrm{A}$ (1) were measured in $\mathrm{CDCl}_{3}$ (data not shown), which were identical with those of monorden (radicicol) previously reported ${ }^{4 \sim 6)}$. Physico-chemical properties and ${ }^{1} \mathrm{H}$ - and ${ }^{13} \mathrm{C}-\mathrm{NMR}$ data in $\mathrm{CD}_{3} \mathrm{OD}$ of monordens $\mathrm{B}(2), \mathrm{C} \mathrm{(3),} \mathrm{D} \mathrm{(4)} \mathrm{and} \mathrm{E}(5)$ are summarized in Tables 1, 2 and 3 together with those of $\mathbf{1}$ for comparative purpose. Monorden $\mathrm{B}$ (2) and 5-Omethylsclerone were reported as synthetic compounds.

\section{Structure of Monorden C (3)}

The molecular formula of the compound $\mathbf{3}$, given yellowish amorphous powder, was established as $\mathrm{C}_{18} \mathrm{H}_{19} \mathrm{O}_{6} \mathrm{Cl}$ on the basis of HRFAB-MS [ $\mathrm{m} / \mathrm{z} 365.0809$ $(\mathrm{M}-\mathrm{H})^{+}, 365.0792$ for $\mathrm{C}_{18} \mathrm{H}_{18} \mathrm{O}_{6} \mathrm{Cl}$. The UV spectrum of 3 showed maxima absorption, $\lambda_{\max } \mathrm{nm}\left(\varepsilon, \mathrm{CH}_{3} \mathrm{OH}\right): 218$ $(27,200), 227$ (sh, 20,900), 261 (6,900), 313 (4,800). These spectra resemble those of 1 , suggesting that 3 has structure related to 1 .

The ${ }^{13} \mathrm{C}$-NMR spectra of $\mathbf{3}$ in $\mathrm{CD}_{3} \mathrm{OD}$ exhibited 18 carbon signals. Analysis of the ${ }^{1} \mathrm{H}-,{ }^{13} \mathrm{C}-\mathrm{NMR}$, DEPT and HMQC spectral data led to the existence of one doublet methyl, four methylene, three $s p^{3}$ methine, three $s p^{2}$ methine, seven quaternary carbons. The ${ }^{1} \mathrm{H}-{ }^{1} \mathrm{H}$ COSY and HMBC spectra of 3 revealed a partial connection consisting of one methyl, three methylene, three $s p^{3}$ methine and two $s p^{2}$ methine, which assigned the sequence from C-1 to C-9. Further structural elucidation was done through interpretation of the HMBC experiment of 3 as shown in Fig. 2. The ${ }^{1} \mathrm{H}-{ }^{13} \mathrm{C}$ long-range couplings from $8-\mathrm{H}\left(\delta_{\mathrm{H}}\right.$ 7.02) to C-10 $\left(\delta_{\mathrm{C}} 199.0\right)$, and from $9-\mathrm{H}\left(\delta_{\mathrm{H}} 6.11\right)$ to $\mathrm{C}-10$ and $\mathrm{C}-11\left(\delta_{\mathrm{C}} 45.8\right)$, and from $11-\mathrm{H}_{2}\left(\delta_{\mathrm{H}} 4.59\right.$ and 4.36$)$ to C-10 and C-9 $\left(\delta_{\mathrm{C}} 132.0\right)$ gave the bond from C-9 to C-11 via $\mathrm{C}-10$. The long-range couplings from $15-\mathrm{H}\left(\delta_{\mathrm{H}} 6.46\right)$ to C-13 $\left(\delta_{\mathrm{C}} 117.5\right), \mathrm{C}-14\left(\delta_{\mathrm{C}} 164.8\right), \mathrm{C}-16\left(\delta_{\mathrm{C}} 160.8\right)$ and C-

* Corresponding author: tomoda@lisci.kitasato-u.ac.jp or omura-s@kitasato.or.jp 
Fig. 1. The structures of monordens A (1), B (2), C (3), D (4), E (5) and 5-O-methylsclerone (6).<smiles>CC(C)(C[C@]1(C)O[C@@H]1/C=C\C=C/C(=O)Cc1c(O)ccc(O)c1Cl)OC(=O)c1ccccc1O</smiles>

Monorden A (Mnorden, Radicicol)<smiles>COC(C)CC1OC1CCCCC(=O)Cc1c(Cl)c(O)cc(O)c1C(=O)OC1CC1</smiles>

Monorden B<smiles>COC(C)CC1OC1CC/C=C/C(=O)Cc1c(Cl)c(O)cc(O)c1C(=O)O</smiles>

Monorden C<smiles>CCC(C)C/C=C/CC/C=C/C(=O)Cc1c(Cl)c(O)cc(O)c1C(=O)O</smiles>

Monorden D<smiles></smiles>

Monorden E<smiles>COc1cccc2c1C(O)CCC2=O</smiles>

5-O-Methylsclerone
$17\left(\delta_{\mathrm{C}} 108.2\right)$ suggested that 3 contains the pentasubstituted benzene moiety, because $15-\mathrm{H}$ was only observed as a singlet in the low-field signal. The long-range couplings from $11-\mathrm{H}$ to $\mathrm{C}-12\left(\delta_{\mathrm{C}} 137.9\right), \mathrm{C}-13$ and $\mathrm{C}-17$ indicated that $\mathrm{C}-12$ is linked to $\mathrm{C}-11$. The carbon chemical shifts for benzene moiety showed good agreement with those of 1 , suggesting that the corresponding part is 1,2disubstituted 3-chloro-4,6-dihydroxybenzene. The longrange coupling through 4 bonds $\left({ }^{4} J\right)$ from $15-\mathrm{H}$ to $\mathrm{C}-18\left(\delta_{\mathrm{C}}\right.$ 171.9) was observed, indicating that they are for ' $\mathrm{W}$ ' configuration and that $\mathrm{C}-17$ and $\mathrm{C}-18$ are bonded. The geometrical isomerism of $\mathrm{C}-8$ was determined as ' $E$ ' by the proton coupling constant of $J_{8,9}(16.0 \mathrm{~Hz})$. Thus, the planer structure of $\mathbf{3}$ was elucidated as 8-chloro1a,4,5,14,15,15a-hexahydro-9,11-dihydroxy-14-methyl-6H- oxireno $[e][2]$ benzoxacyclotetradecin-6,12(7H)-dione.

\section{Structure of Monorden D (4)}

The molecular formula of the compound $\mathbf{4}$, given yellowish oil, was established as $\mathrm{C}_{18} \mathrm{H}_{19} \mathrm{O}_{5} \mathrm{Cl}$ on the basis of

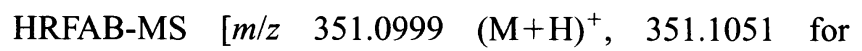
$\mathrm{C}_{18} \mathrm{H}_{20} \mathrm{O}_{5} \mathrm{Cl}$. The UV and IR of 4 were very similar to those of 1 and $\mathbf{3}$.

The ${ }^{13} \mathrm{C}$-NMR spectra of 4 in $\mathrm{CD}_{3} \mathrm{OD}$ exhibited 18 carbon signals as well as those of 1 and 3 . The ${ }^{1} \mathrm{H}-$ and ${ }^{13} \mathrm{C}$-NMR spectra of 4 showed signals of the 1,2disubstituted 3-chloro-4,6-dihydroxybenzene moiety $\left(\delta_{\mathrm{C}}\right.$ $162.7,159.3,137.1,116.5,109.6$ and 103.9, $\left.\delta_{\mathrm{H}} 6.48\right)$, two carbonyl $\left(\delta_{\mathrm{C}} 198.7\right.$ and 170.7$)$ and methylene $\left(\delta_{\mathrm{C}} 46.4\right.$, $\delta_{\mathrm{H}} 4.23$ and 4.11$)$ between the substituted benzene and 
Table 1. Physico-chemical properties of monordens A (1), B (2), C (3), D (4) and E (5).

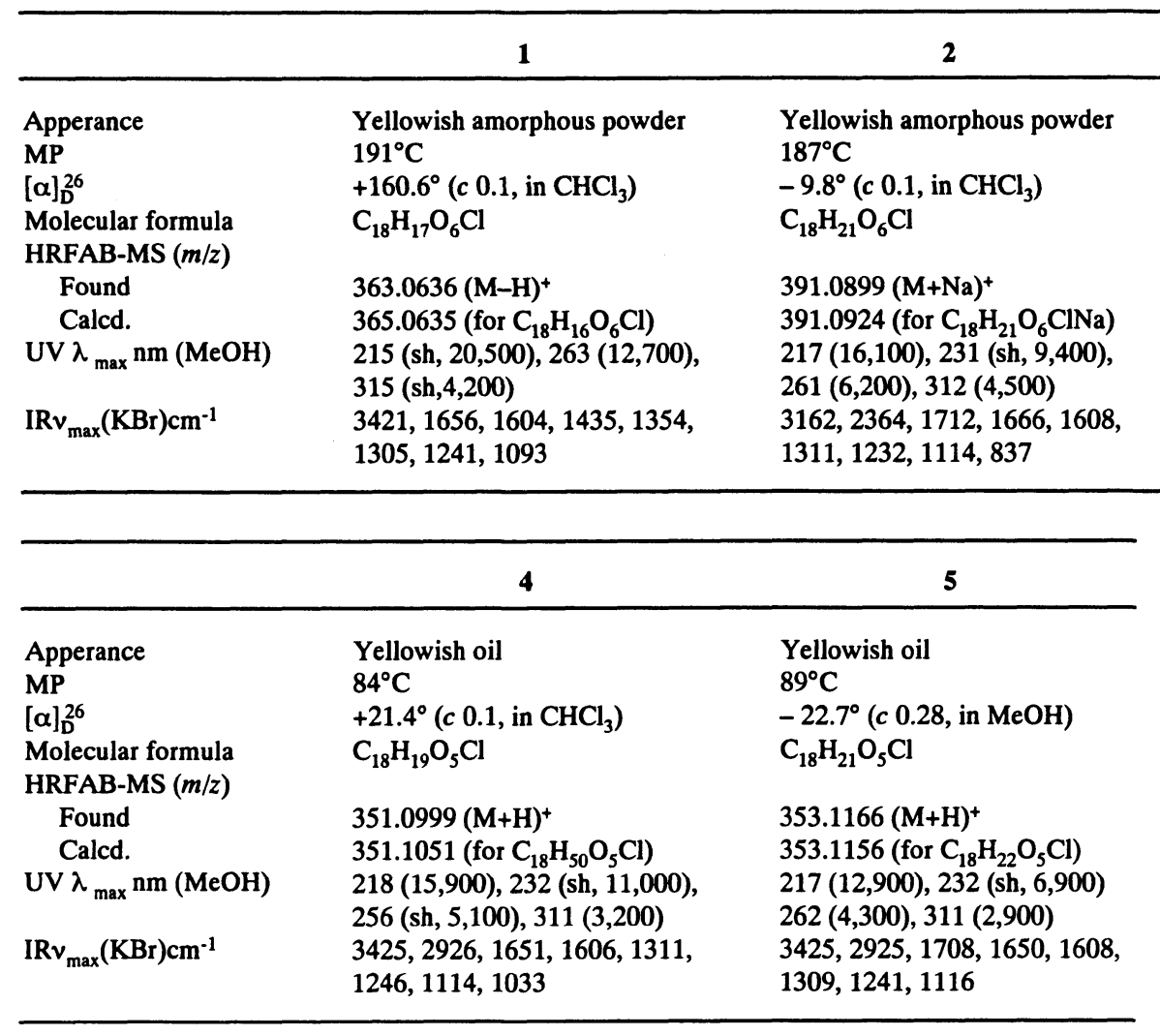

Table 2. The ${ }^{13} \mathrm{C}-\mathrm{NMR}$ data of monordens $\mathrm{A}(\mathbf{1}), \mathrm{B}(\mathbf{2}), \mathrm{C}(\mathbf{3}), \mathrm{D}(\mathbf{4})$ and $\mathrm{E}(5)$ in $\mathrm{CD}_{3} \mathrm{OD}$.

\begin{tabular}{|c|c|c|c|c|c|}
\hline Position & $\delta_{\mathrm{C}}(\mathrm{ppm}, J$ in $\mathrm{Hz})$ & $\delta_{C}(\mathrm{ppm}, J$ in $\mathrm{Hz})$ & $\delta_{\mathrm{C}} \stackrel{3}{3}$ & $\delta_{\mathrm{C}} \stackrel{4}{\mathrm{ppm}, J \text { in } \mathrm{Hz})}$ & $\stackrel{5}{\delta_{\mathrm{C}}(\mathrm{ppm}, J \text { in } \mathrm{Hz})}$ \\
\hline 1 & $19.2 \mathrm{q}$ & $19.5 \mathrm{q}$ & $18.5 q$ & $18.5 q$ & $19.4 \mathrm{q}$ \\
\hline 2 & $72.6 \mathrm{~d}$ & $72.4 \mathrm{~d}$ & $74.0 \mathrm{~d}$ & $73.7 \mathrm{~d}$ & $74.2 \mathrm{~d}$ \\
\hline 3 & $38.2 \mathrm{t}$ & $37.9 \mathrm{t}$ & $38.0 \mathrm{t}$ & $38.1 \mathrm{t}$ & $38.9 t$ \\
\hline 4 & $57.0 \mathrm{~d}$ & $56.4 \mathrm{~d}$ & $57.2 \mathrm{~d}$ & $128.1 \mathrm{~d}$ & $126.5 \mathrm{~d}$ \\
\hline 5 & $57.3 \mathrm{~d}$ & $58.7 \mathrm{~d}$ & $58.6 \mathrm{~d}$ & $133.4 \mathrm{~d}$ & $135.7 \mathrm{~d}$ \\
\hline 6 & $137.4 d^{\text {a) }}$ & $31.5 \mathrm{t}$ & $32.4 \mathrm{t}$ & $32.1 \mathrm{t}$ & $33.2 \mathrm{t}$ \\
\hline 7 & $132.0 \mathrm{~d}^{\text {a) }}$ & $24.5 \mathrm{t}$ & $30.6 \mathrm{t}$ & $32.3 \mathrm{t}$ & $26.8 \mathrm{t}$ \\
\hline 8 & $141.1 d^{\text {a) }}$ & $23.9 t$ & $150.9 \mathrm{~d}$ & $149.3 \mathrm{~d}$ & $23.4 \mathrm{t}$ \\
\hline 9 & $131.3 d^{\text {a) }}$ & $41.4 \mathrm{t}$ & $132.0 \mathrm{~d}$ & $130.8 \mathrm{~d}$ & $42.1 \mathrm{t}$ \\
\hline 10 & $200.1 \mathrm{~s}$ & $209.7 \mathrm{~s}$ & $199.0 \mathrm{~s}$ & $198.7 \mathrm{~s}$ & $209.7 \mathrm{~s}$ \\
\hline 11 & $47.0 \mathrm{t}$ & $47.1 \mathrm{t}$ & $45.8 \mathrm{t}$ & $46.4 \mathrm{t}$ & $47.1 \mathrm{t}$ \\
\hline 12 & $135.6 \mathrm{~s}$ & $136.1 \mathrm{~s}$ & $137.9 \mathrm{~s}$ & $137.1 \mathrm{~s}$ & $137.1 \mathrm{~s}$ \\
\hline 13 & $115.8 \mathrm{~s}$ & $116.0 \mathrm{~s}$ & $117.5 \mathrm{~s}$ & $116.5 \mathrm{~s}$ & $116.1 \mathrm{~s}$ \\
\hline $14^{\circ}$ & $159.6 \mathrm{~s}$ & $161.3 \mathrm{~s}$ & $164.8 \mathrm{~s}$ & $162.7 \mathrm{~s}$ & $162.6 \mathrm{~s}$ \\
\hline 15 & $104.3 \mathrm{~d}$ & $103.9 \mathrm{~d}$ & $104.5 \mathrm{~d}$ & $103.9 \mathrm{~d}$ & $103.9 \mathrm{~d}$ \\
\hline 16 & $158.8 \mathrm{~s}$ & $159.1 \mathrm{~s}$ & $160.8 \mathrm{~s}$ & $159.3 \mathrm{~s}$ & $159.1 \mathrm{~s}$ \\
\hline 17 & $113.6 \mathrm{~s}$ & $110.8 \mathrm{~s}$ & $108.2 \mathrm{~s}$ & $109.6 \mathrm{~s}$ & $109.8 \mathrm{~s}$ \\
\hline 18 & $169.6 \mathrm{~s}$ & $170.6 \mathrm{~s}$ & $171.9 \mathrm{~s}$ & $170.7 \mathrm{~s}$ & $171.1 \mathrm{~s}$ \\
\hline
\end{tabular}

a) Assignments are interchangeable 
Table 3. The ${ }^{1} \mathrm{H}-\mathrm{NMR}$ data of monordens A (1), B (2), C (3), D (4) and $\mathrm{E}(5)$ in $\mathrm{CD}_{3} \mathrm{OD}$.

\begin{tabular}{|c|c|c|c|}
\hline Position & $\delta_{\mathrm{H}} \stackrel{1}{1}$ & $\delta_{\mathrm{H}} \stackrel{2}{2}(\mathrm{ppm}, J$ in $\mathrm{Hz})$ & $\delta_{H}(\mathrm{ppm}, J$ in $\mathrm{Hz})$ \\
\hline 1 & $1.51 \mathrm{~d}(3 \mathrm{H}, J=6.6 \mathrm{~Hz})$ & $1.43 \mathrm{~d}(3 \mathrm{H}, J=6.4 \mathrm{~Hz})$ & $1.46 \mathrm{~d}(3 \mathrm{H}, J=6.5 \mathrm{~Hz})$ \\
\hline 2 & $5.37 \mathrm{~m}(1 \mathrm{H})$ & $5.27 \mathrm{~m} \mathrm{(1H)}$ & $5.23 \mathrm{~m}(1 \mathrm{H})$ \\
\hline \multirow[t]{2}{*}{3} & $2.41 \mathrm{ddd}(1 \mathrm{H}, J=14.7,3.4,3.0 \mathrm{~Hz})$ & 2.17 ddd $(1 \mathrm{H}, J=15.2,6.9,4.1 \mathrm{~Hz})$ & 2.04 br. dd $(1 \mathrm{H}, J=16.1,3.4 \mathrm{~Hz})$ \\
\hline & 1.72 ddd $(1 \mathrm{H}, J=14.7,8.6,3.9 \mathrm{~Hz})$ & $1.77 \mathrm{~m}(1 \mathrm{H})$ & 1.76 ddd $(1 \mathrm{H}, J=16.1,4.8,4.3 \mathrm{~Hz})$ \\
\hline 4 & 3.05 ddd $(1 \mathrm{H}, J=8.6,3.0,2.2 \mathrm{~Hz})$ & $2.84 \mathrm{ddd}(1 \mathrm{H}, J=6.4,4.3,2.5 \mathrm{~Hz})$ & $2.88 \mathrm{~m}(1 \mathrm{H})$ \\
\hline 5 & $3.33 \mathrm{~m}(1 \mathrm{H})$ & $2.71 \mathrm{ddd}(1 \mathrm{H}, J=8.7,3.0,2.5 \mathrm{~Hz})$ & $2.60 \mathrm{~m}(1 \mathrm{H})$ \\
\hline \multirow[t]{2}{*}{6} & $5.77 \mathrm{dd}(1 \mathrm{H}, J=10.7,3.9 \mathrm{~Hz})$ & $2.00 \mathrm{~m}(1 \mathrm{H})$ & $2.37 \mathrm{~m}(1 \mathrm{H})$ \\
\hline & & $1.20 \mathrm{~m}(1 \mathrm{H})$ & $1.26 \mathrm{~m}(1 \mathrm{H})$ \\
\hline \multirow[t]{2}{*}{7} & $2.54 \mathrm{ddd}(1 \mathrm{H}, J=10.7,9.8,1.5 \mathrm{~Hz})$ & $1.58 \mathrm{~m}(1 \mathrm{H})$ & $2.54 \mathrm{~m}(1 \mathrm{H})$ \\
\hline & & $1.47 \mathrm{~m}(1 \mathrm{H})$ & $2.33 \mathrm{~m}(1 \mathrm{H})$ \\
\hline \multirow[t]{2}{*}{8} & $7.52 \mathrm{dd}(1 \mathrm{H}, J=16.9,9.8 \mathrm{~Hz})$ & $1.58 \mathrm{~m}(1 \mathrm{H})$ & $7.02 \mathrm{ddd}(1 \mathrm{H}, J=16.0,10.8,4.4 \mathrm{~Hz})$ \\
\hline & & $1.77 \mathrm{~m}(1 \mathrm{H})$ & \\
\hline \multirow[t]{2}{*}{9} & $6.11 \mathrm{~d}(1 \mathrm{H}, J=16.9 \mathrm{~Hz})$ & $2.56 \mathrm{~m}(1 \mathrm{H})$ & $6.11 \mathrm{dd}(1 \mathrm{H}, J=16.0,1.4 \mathrm{~Hz})$ \\
\hline & & $2.50 \mathrm{~m}(1 \mathrm{H})$ & \\
\hline \multirow[t]{2}{*}{11} & $4.16 \mathrm{~d}(1 \mathrm{H}, J=16.3 \mathrm{~Hz})$ & $4.30 \mathrm{~d}(1 \mathrm{H}, J=18.2 \mathrm{~Hz})$ & $4.59 \mathrm{~d}(1 \mathrm{H}, J=18.3 \mathrm{~Hz})$ \\
\hline & $3.92 \mathrm{~d}(1 \mathrm{H}, J=16.3 \mathrm{~Hz})$ & $4.20 \mathrm{~d}(1 \mathrm{H}, J=18.2 \mathrm{~Hz})$ & $4.36 \mathrm{~d}(1 \mathrm{H}, J=18.3 \mathrm{~Hz})$ \\
\hline 15 & $6.46 \mathrm{~s}(1 \mathrm{H})$ & $6.45 \mathrm{~s}(1 \mathrm{H})$ & $6.46 \mathrm{~s}(1 \mathrm{H})$ \\
\hline
\end{tabular}

\begin{tabular}{|c|c|c|}
\hline Position & $\delta_{\mathrm{H}} \stackrel{4}{4}$ (ppm, $J$ in $\left.\mathrm{Hz}\right)$ & $\delta_{H}(\mathrm{ppm}, J$ in $\mathrm{Hz})$ \\
\hline 1 & $1.29 \mathrm{~d}(3 \mathrm{H}, J=6.4 \mathrm{~Hz})$ & $1.37 \mathrm{~d}(3 \mathrm{H}, J=6.0 \mathrm{~Hz})$ \\
\hline 2 & $5.31 \mathrm{~m}(1 \mathrm{H})$ & $5.31 \mathrm{~m}(1 \mathrm{H})$ \\
\hline \multirow[t]{2}{*}{3} & $2.54 \mathrm{~m}(1 \mathrm{H})$ & $2.50 \mathrm{~m} \mathrm{(1H)}$ \\
\hline & $2.24 \mathrm{~m}(1 \mathrm{H})$ & $2.31 \mathrm{~m} \mathrm{(1H)}$ \\
\hline 4 & $5.28 \mathrm{~m} \mathrm{(1H)}$ & $5.48 \mathrm{~m}(1 \mathrm{H})$ \\
\hline 5 & $5.23 \mathrm{~m}(1 \mathrm{H})$ & $5.48 \mathrm{~m}(1 \mathrm{H})$ \\
\hline 6 & $2.17 \mathrm{~m} \mathrm{(2H)}$ & $2.08 \mathrm{~m} \mathrm{(2H)}$ \\
\hline \multirow[t]{2}{*}{7} & $2.28 \mathrm{~m}(1 \mathrm{H})$ & $1.55 \mathrm{~m} \mathrm{(1 \textrm {H } )}$ \\
\hline & $2.15 \mathrm{~m}(1 \mathrm{H})$ & $1.47 \mathrm{~m} \mathrm{(1H)}$ \\
\hline 8 & $6.72 \mathrm{ddd}(1 \mathrm{H}, J=15.2,8.0,7.0 \mathrm{~Hz})$ & $1.65 \mathrm{~m} \mathrm{(2H)}$ \\
\hline 9 & $5.81 \mathrm{~d}(1 \mathrm{H}, J=15.2 \mathrm{~Hz})$ & $2.52 \mathrm{~m}(2 \mathrm{H})$ \\
\hline \multirow[t]{2}{*}{11} & $4.23 \mathrm{~d}(1 \mathrm{H}, J=16.0 \mathrm{~Hz})$ & $4.37 \mathrm{~d}(1 \mathrm{H}, J=17.0 \mathrm{~Hz})$ \\
\hline & $4.11 \mathrm{~d}(1 \mathrm{H} ; J=16.0 \mathrm{~Hz})$ & $4.09 \mathrm{~d}(1 \mathrm{H}, J=17.0 \mathrm{~Hz})$ \\
\hline 15 & $6.48 \mathrm{~s}(1 \mathrm{H})$ & $6.46 \mathrm{~s}(1 \mathrm{H})$ \\
\hline
\end{tabular}

the ketone, which are common to $\mathbf{1}$ and $\mathbf{3}$. Analysis of the ${ }^{1} \mathrm{H}-,{ }^{13} \mathrm{C}-\mathrm{NMR}$, DEPT, and HMQC spectra revealed the presence of seven quaternary, six methine, four methylene, and one methyl carbons. Four partial structures, $\mathrm{CH}_{3}-\mathrm{CH}(-\mathrm{O})-,-\mathrm{CH}_{2}-\mathrm{CH}=,=\mathrm{CH}-\mathrm{CH}_{2}-$, and $-\mathrm{CH}_{2}-\mathrm{CH}=\mathrm{CH}-$, were shown by ${ }^{1} \mathrm{H}-{ }^{1} \mathrm{H}-\mathrm{COSY}$. Their connection was analysed by HMBC (Fig. 2), indicating that 4 contains the olefin bonds between $\mathrm{C}-8$ and C-9 and between $\mathrm{C}-4$ and $\mathrm{C}-5$. Further structural elucidation was also made by interpreting the HMBC experimental data (Fig. 2). Finally, the planar structure of 4 was elucidated as 13-chloro-3,4,7,8-tetrahydro-14,16dihydroxy-3-methyl-1H-2-benzoxacyclotetradecin1,11(12H)-dione.

\section{Structure of Monorden E (5)}

The molecular formula of the compound 5 was established as $\mathrm{C}_{18} \mathrm{H}_{21} \mathrm{O}_{5} \mathrm{Cl}$ on the basis of HRFAB-MS $[\mathrm{m} / \mathrm{z}$ $353.1166(\mathrm{M}+\mathrm{H})^{+}, 353.1156$ for $\mathrm{C}_{18} \mathrm{H}_{22} \mathrm{O}_{5} \mathrm{Cl}$ ], which is additional in two hydrogens compared with 4 . The UV and IR of 5 were very similar to those of 1,3 and 4 .

The NMR spectra of 5 were almost the same as those of 4 except C-7 $\left(\delta_{\mathrm{C}} 26.8, \delta_{\mathrm{H}} 1.47\right.$ and 1.55$)$, C-8 $\left(\delta_{\mathrm{C}} 23.4\right.$, $\left.\delta_{\mathrm{H}} 1.65\right)$, and $\mathrm{C}-9\left(\delta_{\mathrm{C}} 42.1, \delta_{\mathrm{H}} 2.52\right)$. Their alignment was elucidated by ${ }^{1} \mathrm{H}-{ }^{1} \mathrm{H}-\mathrm{COSY}$, and ${ }^{1} \mathrm{H}-{ }^{13} \mathrm{C}$ long-range couplings between $\mathrm{H}_{2}-6\left(\delta_{\mathrm{H}} 2.08\right)$ and $\mathrm{C}-8$, between $\mathrm{H}_{2}-7$ and $\mathrm{C}-5\left(\delta_{\mathrm{C}} 135.7\right)$, between $\mathrm{H}-8$ and $\mathrm{C}-10\left(\delta_{\mathrm{C}} 209.7\right)$, and between $\mathrm{H}-9$ and $\mathrm{C}-10$, suggesting that 5 is 8,9dihydromonorden D. Further structural elucidation was 
Fig. 2. $\quad{ }^{1} \mathrm{H}-{ }^{1} \mathrm{H}$ COSY and HMBC correlations of monordens B (2), C (3), D (4) and $\mathrm{E}(5)$.

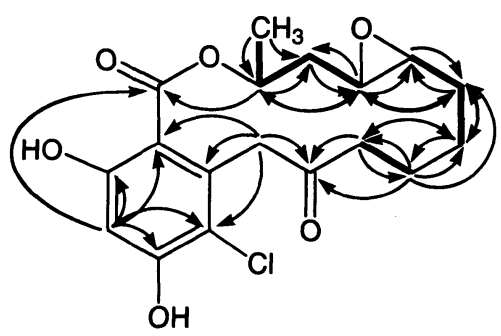

Monorden B

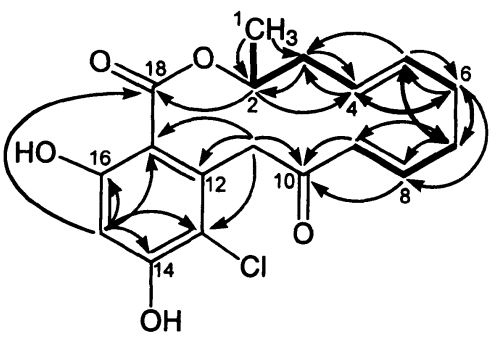

Monorden D

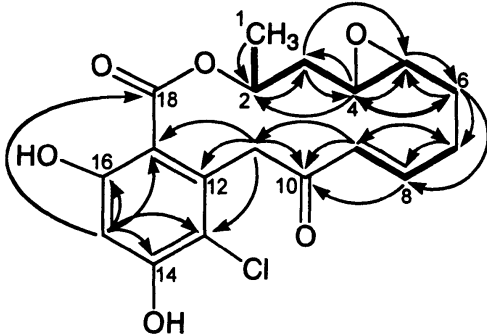

Monorden C

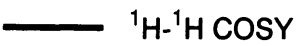
$\frown \mathrm{HMBC}$ made by interpreting the HMBC experimental data as shown in Fig. 2. Finally, the planar structure of 5 was elucidated as 13-chloro-3,4,7,8,9,10-hexahydro-14,16dihydroxy-3-methyl-1H-2-benzoxacyclotetradecin1,11(12H)-dione.

\section{Structure of Monorden B (2)}

The molecular formula of the compound 2 was established as $\mathrm{C}_{18} \mathrm{H}_{21} \mathrm{O}_{6} \mathrm{Cl}$ on the basis of HRFAB-MS [ $\mathrm{m} / \mathrm{z}$ $391.0899(\mathrm{M}+\mathrm{Na})^{+}, 391.0924$ for $\mathrm{C}_{18} \mathrm{H}_{21} \mathrm{O}_{6} \mathrm{ClNa}$, which is $2 \mathrm{H}$ larger than 3 . The UV and IR of 2 were very similar to those of $\mathbf{3}$.

The ${ }^{13} \mathrm{C}$-NMR spectra of 2 in $\mathrm{CD}_{3} \mathrm{OD}$ exhibited 18 carbon signals as well as those of 3 . The ${ }^{1} \mathrm{H}$ - and ${ }^{13} \mathrm{C}-\mathrm{NMR}$ spectra of 2 were almost the same as those of $\mathbf{3}$ except $\mathrm{C} 7$ $\left(\delta_{\mathrm{C}} 24.5, \delta_{\mathrm{H}} 1.58\right.$ and 1.47$), \mathrm{C} 8\left(\delta_{\mathrm{C}} 23.9, \delta_{\mathrm{H}} 1.77\right.$ and 1.58$)$, and $\mathrm{C} 9\left(\delta_{\mathrm{C}} 41.4, \delta_{\mathrm{H}} 2.56\right.$ and 2.50$)$. The ${ }^{1} \mathrm{H}-,{ }^{13} \mathrm{C}-\mathrm{NMR}$, DEPT and HMQC spectral data of 2 indicated the existence of one doublet methyl, six methylene, three $s p^{3}$ methine, one $s p^{2}$ methine and seven quaternary carbons, which were two more methylene and two less $s p^{2}$ methine than those of 3. The connection from $\mathrm{C}-1$ to $\mathrm{C}-10$ via $\mathrm{C}-2,9$ was proved by ${ }^{1} \mathrm{H}-{ }^{1} \mathrm{H}$ COSY and ${ }^{1} \mathrm{H}-{ }^{13} \mathrm{C}$ long-range couplings, suggesting that 2 has additional two hydrogens at C-8 and
C-9 of 3. Further structural elucidation was made by interpreting the HMBC experimental data as shown in Fig. 2. Finally, the structure of $\mathbf{2}$ was elucidated as 8-chloro1a,2,3,4,5,14,15,15a-octahydro-9,11-dihydroxy-14-methyl$6 H$-oxireno[e][2]benzoxacyclotetradecin-6,12(7H)-dione.

Structure of 5-O-Methylsclerone (6)

The molecular formula of the compounds $6,[\alpha]_{\mathrm{D}}^{26}$ $-14.0^{\circ}$ ( $c$ 0.05, in $\mathrm{CHCl}_{3}$ ); given yellowish oil, were established as $\mathrm{C}_{11} \mathrm{H}_{12} \mathrm{O}_{3}$ on the basis of HREI-MS [ $\mathrm{m} / \mathrm{z}$ $192.0709\left(\mathrm{M}^{+}\right), 192.0786$ for $\left.\mathrm{C}_{11} \mathrm{H}_{18} \mathrm{O}_{3}\right]$. The UV spectrum of 6 showed maxima absorption, $\lambda_{\max } \mathrm{nm}\left(\varepsilon, \mathrm{CH}_{3} \mathrm{OH}\right): 226$ $(10,800), 258(3,300), 318(1,200)$. The IR spectrum of 6 showed absorption band, $v_{\max }(\mathrm{KBr}) \mathrm{cm}^{-1}$ : 3382, 1681, 1384, 1211 and 1136.

The ${ }^{13} \mathrm{C}$-NMR spectra of 6 in $\mathrm{CDCl}_{3}$ exhibited 11 carbon signals. Analysis of the ${ }^{1} \mathrm{H}-,{ }^{13} \mathrm{C}-\mathrm{NMR}$, DEPT and HMQC spectral data led to the existence of one singlet methyl $\left(\delta_{\mathrm{C}}\right.$ $\left.55.8, \delta_{\mathrm{H}} 3.94\right)$, two methylene $\left(\delta_{\mathrm{C}} 33.7, \delta_{\mathrm{H}} 2.99,2.55 ; \delta_{\mathrm{C}}\right.$ $\left.29.4, \delta_{\mathrm{H}} 2.34,2.31\right)$, one $s p^{3}$ methine $\left(\delta_{\mathrm{C}} 62.2, \delta_{\mathrm{H}} 5.29\right)$, three $s p^{2}$ methine $\left(\delta_{\mathrm{C}} 129.1, \delta_{\mathrm{H}} 7.39 ; \delta_{\mathrm{C}} 119.0, \delta_{\mathrm{H}} 7.65 ; \delta_{\mathrm{C}}\right.$ $\left.115.3, \delta_{\mathrm{H}} 7.12\right)$, one carbonyl $\left(\delta_{\mathrm{C}} 198.0\right)$ and three aromatic quaternary $\left(\delta_{\mathrm{C}} 157.0,132.5,132.3\right)$ carbons. The chemical shift of methyl, $s p^{3}$ methine and one aromatic quaternary 
carbons suggested that 6 had three oxygenated carbons at $\delta_{\mathrm{C}} 55.7, \delta_{\mathrm{C}} 62.2$ and $\delta_{\mathrm{C}}$ 157.0. The ${ }^{1} \mathrm{H}$-NMR data gave spin network system among C-6 $\left(\delta_{\mathrm{H}} 7.12, \quad J=8.24\right.$, $1.10 \mathrm{~Hz}), \mathrm{C}-7\left(\delta_{\mathrm{H}} 7.39, J=8.24,7.87 \mathrm{~Hz}\right)$ and $\mathrm{C}-8\left(\delta_{\mathrm{H}} 7.65\right.$, $J=7.87,1.10 \mathrm{~Hz}$ ) as ortho- and/or meta-coupling on the benzene ring. Further structural elucidation was made by interpreting the HMBC experimental data for 6 (data not shown). Finally, the structure of 6 was determined as 2,3dihydro-4-hydroxy-5-methoxy-1-naphtalenone.

\section{Discussion}

Analogs of monorden A (radicicol) ${ }^{3)}$ such as monocillins I to $\mathrm{V}^{9}$, nordinone and nordinonediol ${ }^{10)}$ have been reported as fungal metabolites. Although most of them lack the residue, only monorden $\mathrm{A}$ and 13-chloro-6,7,8-dehydro-4hydroxymonocillin $\mathrm{IV}^{11)}$ possess the chlorine residue at $\mathrm{C}$ 13. As described in this paper, all the monordens isolated from the amidepsine producer were found to have the 13chlorine residue in common. Monordens B, C, D and E correspond to 13-chlorinated monocillins III, V, II and IV, respectively. Monorden $\mathrm{B}^{4,7)}$ and 5-O-methylsclerone ${ }^{8)}$ were reported as synthetic compounds, but they were isolated as metabolites of this fungus.

\section{Experimental}

Spectral and physico-chemical data for monorden $\mathrm{A}$ to $\mathrm{E}$ and 5-O-methylsclerone were obtained by the following instruments: $\mathrm{mp}$, Yanagimoto Micro Melting Point Apparatus MP-S3; IR, HORIBA FT-210; UV, HITACHI 340 Recording Spectrophotometer; Optical rotations, JASCO DIP-1000 Digital Polarimeter with a $5 \mathrm{~cm}$ cell; and NMR, Varian UNITY 400. FAB-MS data for. monordens $A$ to $E$ were obtained by JOEL JSM-700 MS station, and EI-MS data for 5-O-methylsclerone was obtained by JOEL JSM-AX 505 HA. All NMR spectra for monorden $\mathrm{A}$ to $\mathrm{E}$ were measured in methanol- $d_{4}$, and peak positions are expressed in parts per million (ppm) based on the reference of methanol peak at $\delta 3.30 \mathrm{ppm}$ for ${ }^{1} \mathrm{H}-\mathrm{NMR}$ and $\delta 49.0 \mathrm{ppm}$ for ${ }^{13} \mathrm{C}-\mathrm{NMR}$. Monorden $\mathrm{A}$ were also measured in chloroform- $d$. All NMR spectra for 5-Omethylsclerone were also measured in chloroform- $d$, and peak positions are expressed in parts per million (ppm) based on the reference of chloroform peak at $\delta 7.24 \mathrm{ppm}$ for ${ }^{1} \mathrm{H}-\mathrm{NMR}$ and $\delta 77.0 \mathrm{ppm}$ for ${ }^{13} \mathrm{C}$-NMR. All FAB-MS spectra were measured using 3-nitrobenzylalcohol and thioglycerol for matrix.

\section{Acknowledgments}

We express our thanks to Ms. N. SATO, School of Pharmaceutical Sciences, Kitasato University, for measurement of NMR spectra.

This study was supported in part by the grand of the 21 st Century COE Program, Ministry of Education, Culture, Sports, Science and Technology, Japan.

\section{References}

1) Tomoda, H.; M. Ito, N. TABata, R. Masuma, Y. YAMAGUCHI \& S. ŌMURA: Amidepsins, inhibitors of diacylglycerol acyltransferase produced by Humicola sp. FO-2942. I. Production, isolation and biological properties. J. Antibiotics 48: 937 941, 1995

2) Arai, M.; K. Yamamoto, I. Namatame, H. Tomoda \& S. ŌMURA: New monordens produced by amidepsineproducing fungus Humicola sp. FO-2942. J. Antibiotics 56: 526 532, 2003

3) Delmotte, P. \& J. Delmotte-Plaquee: A new antifungal substance of fungal origin. Nature 171: 344, 1953

4) Mirrington, R. N.; E. Ritchie, C. W. Shoppee, W. C. TAYLOR \& S. STERNHELL: The constitution of radicicol. Tetrahedron Lett. 7: 365 370, 1964

5) Mccapra, F; A. I. Scott, P. Delmotte, J. DelmottePlaqueE \& N. S. BhaccA: The constitution of monorden, an antibiotic with tranquilising action. Tetrahedron Lett. 15: 869 857, 1964

6) NozAWA, K. \& S. NAKAJIMA: Isolation of radicicol from Penicillium luteo-aurantium, and meleagrin, a new metabolite, from Penicillium meleagrinum. J. Nat. Prod. 42: 374 377, 1979

7) Mirrington, R. N.; E. Ritchie, C. W. Shoppee, S. STERNHELL \& W. C. TAYLOR: Some metabolites of Nectria radicicola Gerlach \& Nilsson (syn. Cylindrocarpon radicicola Wr.): The structure of radicicol (monorden). Aust. J. Chem. 19: 1265 1284, 1966

8) Suzuki, K.; T. Sassa, H. Tamnaka, H. AoKi \& M. NAMIKI: Sclerone, a new metabolite of Sclerotinia sclerotiorum (LIB) DE BARY. Agr. Biol. Chem. 32: $1471 \sim 1475,1968$

9) Ayar, W. A.; S. P. Lee, A. Tsuneda \& Y. Hiratsuka: The isolation, identification, and bioassay of the antifungal metabolites produced by Monocillium nordinii. Can. J. Microbiol. 26: 766 773, 1980

10) AYAR, W. A. \& P. R. LuIS: Minor metabolite of Monocillium nordinii. Phytochemistry 26: 1353 1355, 1987

11) Wicklow, T. D.; B. K. Joshi, W. R. Gamble, J. B. Gloer \& P. F. DowD: Antifungal metabolites (monorden, monocillin IV, and cerebrosides) from Humicola fuscoatra Traaen NRRL 22980, a mycoparasite of Asperllus flavus sclerotia. Appl. Environ. Microbiol. 64: 4482 4484, 1998 